\title{
USE OF SOME SELECTED WASTES AS SUSTAINABLE AGRICULTURAL INPUTS
}

\author{
M. R. Islam, M. Z. Abedin, M. Z. Rahman and A. Begum ${ }^{1}$ \\ Department of Farm Structure, Bangladesh Agricultural University \\ Mymensingh-2202 Bangladesh
}

\begin{abstract}
This study elucidates an attempt to prepare compost from kitchen, dairy and drainage wastes and estimate their manorial value, and to examine the effect of prepared compost on the properties of post-harvest soil. The composts on individual item were prepared by the recently practiced quick composting method. The composts were applied in four different plots; three were treated with composts and the rest with no-treatment. The red amaranth was taken as the reference crop for the present study. The plots treated with dairy and kitchen wastes composts conserved the maximum soil moisture, available phosphorus and exchangeable potassium. The compost prepared from dairy wastes showed the best performance in conserving soil organic carbon and organic matter. The kitchen wastes compost supplied the maximum amount of nitrogen content to the soil. The dairy and kitchen wastes compost was better than the drainage wastes compost for sustainable crop production and in improving soil chemical properties and maintaining good soil quality. Dairy wastes compost showed the best performance in terms of canopy developing the plant height and root length. The highest yield was found in dairy and kitchen wastes compost treated plots. For growth and yield of red amaranth, dairy, kitchen and drainage wastes compost were superior to conventional farming as sustainable agricultural inputs.
\end{abstract}

Key words : Waste, Compost, Agricultural inputs

\section{INTRODUCTION}

Most of the soils of Bangladesh have low organic matter content, usually less than $2 \%$ (Bhuiyan, 1994). About $45 \%$ of net cultivable area of the country has less than $1 \%$ organic matter content (BARC, 1999). At this tilting situation, composting of solid waste may play an important role on waste management of the country as well as impart our soils new juvenility (Bari and Koenign, 2002). Organic wastes can be used as compost through recycling of various organic wastes such as dairy, kitchen and drainage wastes for the maintenance of soil fertility which is a prerequisite for long term sustainable agriculture. Organic manure like these amended in the soil can play a vital role in sustaining soil

1 Postgraduate students, Department of Farm Structure, Bangladesh Agricultural University, Mymensingh-2202, Bangladesh 
fertility and crop production than the use of chemical fertilizers. Waste management receives concern both nationally and internationally due to the mounting urgency of identified urban environmental problems. Proper waste management can save citizens from different diseases, improve environmental conditions, promote urban economic development and generate employment (Huda, 2002). To overcome this situation, maintenance and improvement of soil organic matter through regular organic recycling is deemed necessary (Ahmed et al., 1998). However, sufficient research have not yet been carried out in Bangladesh regarding the available macronutrient release from sewage sludge, kitchen and drainage waste and their effects on Red Amaranth yield and soil quality.

Keeping the above facts in view, the present study was undertaken in achieving the following objectives taking Red Amaranth as a test crop: (a) to prepare compost from kitchen, dairy and drainage wastes and know their chemical composition, (b) to test and estimate the manorial value of the prepared composts as agricultural inputs, and (c) to investigate the effect of different composts on the properties of post-harvest soil.

\section{MATERIALS AND METHODS}

The experiment was carried out at selected experimental field in Sylhet sadar upazila, during August through October 2007 to find out the effect of organic compost on soil properties and Red Amaranth quality and its yield. On the basis of availability, nutrient status and environment polluting factors kitchen wastes collected from Sylhet sadar upazila complex residential area, dairy and drainage wastes collected from different drains' of Sylhet city corporation area have been selected for the present study. The chemical constituents (Obtained from laboratory test, SRDI) of the selected wastes are shown in Table 1.

Table 1. Chemical constituent of the selected organic wastes

\begin{tabular}{l|c|c|c|c|c|c|c|c}
\hline $\begin{array}{c}\text { Name of } \\
\text { wastes }\end{array}$ & $\mathrm{pH}$ & $\begin{array}{c}\text { Organic } \\
\text { carbon (\%) }\end{array}$ & $\begin{array}{c}\text { Organic } \\
\text { matter (\%) }\end{array}$ & $\begin{array}{c}\text { Nitrogen } \\
(\%)\end{array}$ & $\begin{array}{c}\text { Phos- } \\
\text { phorus (\%) }\end{array}$ & $\begin{array}{c}\text { Potassium } \\
(\%)\end{array}$ & $\begin{array}{c}\text { Sulphur } \\
(\%)\end{array}$ & $\begin{array}{c}\text { Calcium } \\
(\%)\end{array}$ \\
\hline Kitchen & 7.8 & 36.53 & 62.83 & 2.70 & 0.43 & 0.92 & 0.20 & 1.50 \\
Dairy & 7.2 & 25.08 & 53.13 & 1.20 & 0.80 & 1.80 & 0.43 & 3.31 \\
Drainage & 7.2 & 1.23 & 2.14 & 0.23 & 8.19 & 0.09 & 0.12 & 0.55 \\
\hline
\end{tabular}

After collection, different types of inorganic materials, polyethylene bags, plastics, glass pieces, grabbles etc. were screened from individual waste. Three trenches have been made at the vicinity of the experimental plots, and then prepared compost by the recently practiced quick composting (Handout, DAE, 2007) method. An ideal soil sample was collected from the experimental plot to test the initial soil chemical composition (Obtained from laboratory test, SRDI) prior to the treatment. 
Table 2. Chemical status of initial soil sample

\begin{tabular}{lc}
\hline Soil properties & Values of the parameters \\
\hline Soil pH & 5.5 \\
Soil moisture (\%) & 24.80 \\
Total N (\%) & 0.085 \\
Available P (ppm) & 20 \\
Exchangeable K (meq/100g soil) & 0.22 \\
Organic carbon (\%) & 1.55 \\
Organic matter content $(\%)$ & 1.52 \\
Available S (ppm) & 36 \\
\hline
\end{tabular}

\section{Land preparation}

The experimental field was ploughed several times to obtain a good tilth condition. The land was then leveled and removed the weeds, stubbles and crop residues and finally made the land ready for about a week before sowing the seed. The prepared land was divided into four equal size plots of $5 \times 5 \mathrm{~m}$.

\section{Treatments of the investigation}

The experiment was conducted with four treatments having $\mathrm{T}_{0}$ : No-compost, $\mathrm{T}_{1}$ : Kitchen waste compost, $\mathrm{T}_{2}$ : Dairy waste compost and $\mathrm{T}_{3}$ : Drainage waste compost. Compost was piled in the plot about 4 days before sowing and left for two days and then the composts were mixed thoroughly with soil with the application rate of $5 \mathrm{t}^{-h \mathrm{a}^{-1}}$. The test vegetable crop seeds of Red Amaranth were then sowed. The experimental crop was harvested 34 days after sowing (DAS). The harvested plants were tagged separately and weighed.

\section{Data collection and analysis}

Plant height was measured using a scale from ground level to the tip of the plant. Shoot length was measured using a scale from ground level to the apex. Root length was measured with a scale from to the tip of the longest root at harvest and their average was taken as the root length. The number of leaves was counted at 34 DAS and mean value was taken to observe the increase in the number of leaves. Red Amaranths were harvested at 34 DAS and the yield was calculated per plot in $\mathrm{kg}$ and then it was converted into tons per hectare. Prior to manuring, soil samples from 10 different spots at 0-15 cm depth were randomly collected and those were mixed to make a single sample for analysis. After crop harvest, soil samples were collected again from each plot at 0-15 cm depth. Soil texture was determined by hydrometer method as described by Black (1965). The textural class was obtained by plotting the values in percent of sand, silt and clay to the 'Marshall Triangle' co-ordinate system. The method for the determination of other parameters of the post-harvest soil is given in Table 3. 
Table 3. Study parameters of soil and method of analysis

\begin{tabular}{ll}
\hline \multicolumn{1}{c|}{ Study parameters } & \multicolumn{1}{c}{ Method of analysis } \\
\hline Soil pH & Glass electrode pH meter (Corning pH meter 320) \\
Soil moisture & Standard Gravimetric method \\
Organic carbon & Wet oxidation method (Black, 1965) \\
Total nitrogen content & Micro-Kjeldahl method (Jackson, 1962) \\
Available phosphorus & Bray-II method (Bray and Kurtz, 1945) \\
Exchangeable potassium & Atomic absorption spectrophotometer (Page et al., 1989) \\
\hline
\end{tabular}

\section{RESULTS AND DISCUSSION}

The $\mathrm{p}^{\mathrm{H}}$ of the post-harvest soil was ranged from 5.50 to 5.59 as shown in Table 4. The maximum numerical value (5.59) of soil $\mathrm{p}^{\mathrm{H}}$ was obtained from dairy compost $\left(\mathrm{T}_{2}\right)$ treated plot and the minimum (5.50) was in no-compost $\left(\mathrm{T}_{0}\right)$ treated plot. All the treatments increased the soil moisture except the drainage compost $\left(\mathrm{T}_{3}\right)$ and the no-compost treated ones (Table 4). The dairy compost conserved the highest soil moisture followed by the kitchen waste compost $\left(\mathrm{T}_{1}\right)$. Sharma et al. (2000) observed that the integrated application of farm-yield manure and chemical fertilizer cause significant improvement in water holding capacity of soil. The organic carbon $(\mathrm{C})$ of the post-harvest soil was influenced by the different treatments. The maximum organic $\mathrm{C}(1.75 \%)$ was obtained in dairy compost treated plot. The minimum organic $C(1.06 \%)$ was recorded in drainage compost treated plot as given in Table 4. As the value of organic matter is the product of multiplication of organic C by the Van Bemmelen factor of 1.724 (Piper, 1942), therefore, the dairy compost treated soil contained the maximum amount of organic matter and the drainage compost treated soil had the minimum. The total nitrogen $(\mathrm{N})$ content of post-harvest soil varied among the treatments as shown in Table 4. The highest $\mathrm{N}$ content was $1.174 \%$ in the kitchen waste compost treated $\left(\mathrm{T}_{1}\right)$ soil and the lowest value was $0.080 \%$ with no-compost treated $\left(\mathrm{T}_{0}\right)$ one. Available phosphorus $(\mathrm{P})$ content varied from 18.49 to $21.80 \mathrm{ppm}$ (Table 4). Soils treated with organic compost gave the higher value of available P compared to no-compost treated one. This results are consistent with those obtained by Iftikhar and Qusim (2003). The highest exchangeable potassium (K) content in post-harvest soil was obtained from the plots treated with dairy waste compost (Table 4). The results indicated that exchangeable $\mathrm{K}$ content was higher in soils treated with organic manures than treated with no-compost treated one. Abdel and Hussein (2001) showed that the significant effect of organic manures improve the exchangeable $\mathrm{K}$ in soil. The highest amount of available sulphur was released by the treatment of dairy compost which was $36.08 \mathrm{ppm}$ and the lowest was $35.56 \mathrm{ppm}$ with no-treatment. The maximum plant height $(35.73 \mathrm{~cm})$ was observed in dairy waste compost treated plot and the lowest $(17.13 \mathrm{~cm})$ was obtained in no-compost treated one (Table 5). The maximum shoot length $(28.47 \mathrm{~cm})$ was obtained from dairy waste compost treated soil and the lowest $(12.40 \mathrm{~cm})$ was obtained from no-compost treated soil. At 34 DAS the maximum root length $(5.77 \mathrm{~cm})$ was recorded from dairy waste compost treated plot and the minimum root length was 
obtained from no-compost treated plot (Table 5). The results from Table 5 showed that large leaf numbers were ranged from 6 to 8 and small leaf numbers were from 5 to 15 . Higher leaf number was obtained from dairy waste compost treated plants. Possible reasons behind this result are organic composts that added higher phosphorus and potassium content in soil than farming with no-compost. The yield of Red Amaranth ranged from 1.970 to $11.780 \mathrm{t} \mathrm{ha}^{-1}$ (Table 5). The highest yield of $11.780 \mathrm{t} \mathrm{ha}^{-1}$ was obtained from the plots treated with dairy waste compost and the lowest was $1.970 \mathrm{t} \mathrm{ha}^{-1}$ as recoded in the no-compost treated plot.

Table 4. Effect of organic compost on post-harvest soil properties

\begin{tabular}{c|c|c|c|c|c|c|c|c}
\hline Treatment & $\mathrm{pH}$ & $\begin{array}{c}\text { Moisture } \\
(\%)\end{array}$ & $\begin{array}{c}\text { Organic } \\
\text { carbon } \\
(\%)\end{array}$ & $\begin{array}{c}\text { Organic } \\
\text { matter } \\
(\%)\end{array}$ & $\begin{array}{c}\text { Total N } \\
(\%)\end{array}$ & $\begin{array}{c}\text { Available } \\
\mathrm{P}(\mathrm{ppm})\end{array}$ & $\begin{array}{c}\text { Exchangeable } \\
\mathrm{K}(\mathrm{me} / 100 \mathrm{~g} \text { soil })\end{array}$ & $\begin{array}{c}\text { Available } \\
\mathrm{S}(\mathrm{ppm})\end{array}$ \\
\hline $\mathrm{T}_{0}$ & 5.50 & 24.44 & 1.08 & 1.86 & 0.080 & 18.49 & 0.198 & 35.56 \\
$\mathrm{~T}_{1}$ & 5.57 & 26.56 & 1.61 & 2.78 & 1.174 & 21.74 & 0.202 & 36.03 \\
$\mathrm{~T}_{2}$ & 5.59 & 26.77 & 1.75 & 3.01 & 1.135 & 21.80 & 0.211 & 36.08 \\
$\mathrm{~T}_{3}$ & 5.51 & 24.60 & 1.06 & 1.83 & 0.985 & 18.57 & 0.201 & 37.02 \\
\hline
\end{tabular}

$\mathrm{T}_{0}=$ No-compost, $\mathrm{T}_{1}=$ Kitchen waste compost, $\mathrm{T}_{2}=$ Dairy waste compost, $\mathrm{T}_{3}=$ Drainage waste compost

Table 5. Effect of organic composting on the growth and yield of Red Amaranth at 34 DAS

\begin{tabular}{|c|c|c|c|c|c|c|c|}
\hline \multirow[t]{2}{*}{ Treatment } & \multirow{2}{*}{$\begin{array}{c}\text { Plant } \\
\text { height }(\mathrm{cm})\end{array}$} & \multirow{2}{*}{$\begin{array}{c}\text { Shoot } \\
\text { length }(\mathrm{cm})\end{array}$} & \multirow{2}{*}{$\begin{array}{c}\text { Root } \\
\text { length }(\mathrm{cm})\end{array}$} & \multicolumn{2}{|c|}{ Leaves per plant } & \multirow{2}{*}{$\begin{array}{l}\text { Yield plot }{ }^{-1} \\
\quad(\mathrm{~kg})\end{array}$} & \multirow{2}{*}{$\begin{array}{l}\text { Yield } \\
\left(\mathrm{t} \mathrm{ha}^{-1}\right)\end{array}$} \\
\hline & & & & $\begin{array}{l}\text { Large } \\
\text { leaves }\end{array}$ & $\begin{array}{c}\text { Small } \\
\text { leaves }\end{array}$ & & \\
\hline $\mathrm{T}_{0}$ & 17.13 & 12.40 & 3.43 & 6 & 5 & 0.200 & 1.970 \\
\hline $\mathrm{T}_{1}$ & 34.53 & 25.27 & 5.27 & 7 & 13 & 0.963 & 9.473 \\
\hline $\mathrm{T}_{2}$ & 35.73 & 28.27 & 5.77 & 8 & 15 & 1.197 & 11.780 \\
\hline $\mathrm{T}_{3}$ & 25.33 & 21.00 & 3.57 & 7 & 9 & 0.643 & 6.330 \\
\hline
\end{tabular}

$\mathrm{T}_{0}=$ No-compost, $\mathrm{T}_{1}=$ Kitchen waste compost, $\mathrm{T}_{2}=$ Dairy waste compost, and $\mathrm{T}_{3}=$ Drainage waste compost

\section{CONCLUSION}

The application of compost prepared from dairy and kitchen wastes have the great positive effect in conserving soil moisture, available phosphorus and exchangeable potassium. The compost prepared from dairy wastes showed the highest organic matter. The yield and its contributing parameters were greatly influenced by the different treatments. The prepared composts showed the best performance for plant height and root length of Red Amaranth as reference crop. The highest yield was found in dairy waste compost treated plot. The dairy and kitchen waste compost was superior to conventional farming inputs for growth and yield of selected vegetable crop. The dairy waste compost 
showed its superiority on yield and yield contributing characters of Red Amaranth but kitchen and dairy waste compost showed their superiority on nutrient content and upgrade the soil status after post-harvest condition. In order to maintain good soil quality and crop yield, and keep the environment safe, it would be wise to advise farmers for the application of organic waste composts over conventional farming inputs for sustainable agricultural development.

\section{REFERENCES}

Abdel, N. G. and Hussein, A. H. A. 2001. Effect of different manure sources on some soil properties and sunflower plant growth. Soil physical and chemical properties. Alexandria J. Agril. Res., 46(1): 227-251

Ahmed, M. M., Islam, M. R. and Haq, M. F. 1998. Green manuring of sustainable crop production and soil fertility. Integrated Nutrient Management for Crop Production and Soil Fertility.

BARC, 1999. Land Degradation Situation in Bangladesh. Soil Division. Bangladesh Agril. Res. Coun., Farmgate, Dhaka.

Bari, Q. H. and Koenig, A. 2002. Measuring solid waste compost maturity: a review and practice. Bangladesh Environ., 2002(2): 7-12.

Bhuiyan, N. I. 1994. Crop production trend and need of sustainability in agriculture. A paper presented in a three-day long workshop on integrated nutrients management for sustainable agriculture held at SRDI, Dhaka, June, 26-28.

Black, C. A. 1965. Method of Soil Analysis Part I and II. American Society of Agronomy. Inc. Pub. Madison. Wisconsin, USA.

DAE, 2007. Quick Compost. Department of Agricultural Extension, Farmgate, Dhaka.

Huda, K. M. N. 2002. Municipal solid waste management Dhaka city perspective. In Ahmed. M. F. Tanveer, S.A. and Badruzzaman, A. B. M. (eds) Bangladesh Environment, 2002(2): 732-733.

Iftikhar, A. and Qusim, M. 2003. Influence of various potting media on growth and nutrient uptake efficiency of Scindapsus aureus. Inter. J. Agric. Biol., 11(2): 1-3.

Page, A. L. Miller, R. H. and Kenny, D. R. 1989. Methods Soil Analysis Part 2. Chemical and Microbiological Prooperties. 2nd (Edn.) American Society of Agronomy, Soil Science Society of America, Inc. Publishers, Madison, Wisconsin, USA.

Piper, C. S. 1942. Soil and Plant Analysis. Interscience, New York. pp. 223-227.

Sharma, M. P., Bali, S. V. and Gupta, D. K. 2000. Crop yield and properties of inceptisol as influenced by residue management under rice-wheat cropping Sequence. J. Indian Soc. Soil. Sci. 48(3): 506-509.

SRDI. Soil Resource Development Institute, Sylhet, Bangladesh. 